\title{
Analisis Ketimpangan Perekonomian Terhadap Tingkat Pendidikan Di Kecamatan Prambanan
}

\author{
Muhammad Hafidhudin Anwar*, Mutia Januar Ramadani, Gatot Purbo Utomo, \\ Fitria Febri Murnawi, Abdullah Hadiid Rozi, dan Kurnia Vionilla \\ Program Studi Pendidikan Geografi, FKIP Universitas Muhammadiyah Surakarta
}

*E-mail: hafidanwar20@gmail.com

Received: 09102018 / Accepted: 11122018 / Published online: 17012019

\begin{abstract}
ABSTRAK
Indonesia merupakan negara berkembang di Asia Tenggara. Berbagai problematika di Indonesia cukup banyak, salah satunya permasalahan yaitu disparitas (ketimpangan) pendidikan. Tujuan dari penelitian ini adalah menjelaskan fenomena ketimpangan perekonomian, serta pengaruhnya terhadap tingkat pendidikan masyarakat di Kecamatan Prambanan. Metode yang digunakan adalah analisis deskriptif dan analisis kuantitatif untuk mendeskripsikan bagaimana suatu ketimpangan ekonomi itu dapat mempengaruhi tingkat pendidikan. Sampel dari penelitian ini menggunakan persil bangunan di Kecamatan Prambanan, dengan jumlah sampel 1599 persil bangunan. Teknik pengambilan data dengan menggunakan kuisioner, observasi, dan dokumentasi. Variabel penelitian meliputi pendapatan yang mewakili keadaan perekonomian masyarakat Prambanan. Hasil penelitian menunjukkan bahwa dari 16 desa di Kecamatan Prambanan, adanya keberagam keadaan perekonomian warga. Desa Pereng memiliki tingkat pendapatan paling tinggi dengan rata rata pendapatan lebih dari Rp. 1.500.000, sedang Desa Randusari memiliki tingkat perekonomian paling rendah yaitu rata rata pendapatan kurang dari Rp.500.000. Keragaman ekonomi tersebut dapat mempengaruhi pendidikan. Faktor-faktor yang membuat ekonomi dan pendidikan saling memengaruhi adalah jumlah penghasilan dan pengeluaran tiap bulan dari tiaptiap individu. Hasil penelitian membuktikan bahwa meskipun memiliki tingkat pendapatan yang rendah, tapi masyarakat memiliki kesadaran akan pentingnya pendidikan yang tinggi, mereka tetap menyekolahkan anak-anak mereka di sekolah gratis yang dibiayai oleh negara.
\end{abstract}

Kata Kunci: Ketimpangan, Pendapatan, Pendidikan

\section{ABSTRACT}

Indonesia is a developing country which have many problem, one of them is inequaity of education. Educational issues will encourage interregional disparity. The aim of research to determine the economic inequality toward education level in Prambanan District. The methodology used descriptive and qualitative analysis to describe how the economic inequality can influence the level of education. Samples of research used building parcel in Prambanan District with the number of samples ware 1599 plot of building. Techniques of data collection was used questionnaires, media, and documentation. This study also includes the variables needed to realize Prambanan society economy. Based on the analysis of the data, it can be concluded that from 16 
Jurnal Geografi, Edukasi dan Lingkungan (JGEL) Vol. 3, No. 1, Januari 2019:26-33

P-ISSN: 2579-8499; E-ISSN: 2579-8510

DOI: https://doi.org/10.29405/jgel.v3i1.2990

Website: http://journal.uhamka.ac.id/index.php/jgel

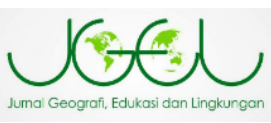

villages in Prambanan Distric showed that Pereng Village has more high rate with average income $R p$. 1,500,000 than Randusari Villages only average income Rp.500.000. Factors that infunce economic and educationa conditions ware the number of income and output. Furthermore, there was finded although the people have low income, they have high aware of importance education.

Keywords: Inequality, Income, Education

\section{PENDAHULUAN}

Indonesia termasuk kedalam negara berkembang di Asia Tenggara, sehingga tingkat pendidikan di Indonesia masih dalam tahap berkembang. Hal tersebut mengakibatkan banyak problematika yang terjadi di Indonesia. Berbagai problematika pendidikan di Indonesia cukup banyak, mulai dari masalah kurikulum, kualitas, kompetensi, bahkan kompetensi kepemimpinan baik itu dijajaran tingkat atas maupun tingkat bawah. Berbagai permasalahan yang terjadi di lapangan, baik pimpinan sekolah maupun para pendidik yang menyayangkan dimensi kepemimpinan seperti soal manajemen, disiplin, birokrasi dan administrasi yang belum maksimal. Kepemimpinan di sekolah yang turut berperan mewarnai wajah penyelenggaraan dunia pendidikan, serta memperlebar kesenjangan dan konflik internal para pendidik.

Salah satu permasalahan pendidikan di Indonesia yang masih besar adalah adanya disparitas. Disparitas merupakan jurang perbedaan atau ketimpangan output pendidikan dalam masyarakat, akibat disparitas tersebut masih banyak ketimpangan sarana prasarana, ketersediaan dan kompetensi guru khususnya di daerah terluar, terdepan dan tertinggal (3T). Tidak ada satupun negara dapat mencapai pembangunan ekonomi yang berkelanjutan tanpa investasi modal manusia secara substansial. Pendidikan memperkaya pemahaman manusia dan dunia. Pendidikan juga meningkatkan kualitas hidup manusia dan manfaat sosial yang lebih luas baik untuk individu maupun masyarakat. Pendidikan meningkatkan produktivitas dan kreativitas tenaga kerja serta meningkatkan kewirausahaan dan kemajuan teknologi. Bahkan, pendidikan memainkan peran yang penting dalam menyelamatkan kemajuan sosial dan ekonomi dan meningkatkan distribusi pendapatan (Ozturk dalam Riswandi, 2009).

Kecamatan Prambanan merupakan salah satu kecamatan di Kabupaten Klaten yang berbatasan langsung dengan Propinsi Daerah Istimewa Yogyakarta (DIY). Meskipun berada di wilayah perbatasan antar provinsi, Kecamatan Prambanan memiliki tingkat pendidikan yang dapat dikatakan baik. Hal tersebut dapat di ketahui dengan perbandingan jumlah sekolah berdasarkan jenjang pendidikan dasar dengan presentase SD $86,8 \%$, MI 2,6 \%, SMP 7,9 \%, MTs 2,6\% (Dinas Pendidikan Provinsi Jawa Tengah). Berdasarkan data Dinas Pendidikan Provinsi Jawa Tengah, dapat diketahui bahwa pada Kecamatan Prambanan memiliki jumlah satuan pendidikan dengan status negeri yang sudah mencukupi namun, jumlah sekolah swasta masih kurang.

Jumlah wisatawan yang berkunjung ke wilayah Prambanan, menurut data BPS Tahun 2017 sekitar 208.090 wisatawan asing dan 1.887.038 wisatawan domestik untuk mengunjungi objek wisata di Kecamatan Prambanan. 
Jurnal Geografi, Edukasi dan Lingkungan (JGEL) Vol. 3, No. 1, Januari 2019:26-33

P-ISSN: 2579-8499; E-ISSN: 2579-8510

DOI: https://doi.org/10.29405/jgel.v3i1.2990

Website: http://journal.uhamka.ac.id/index.php/jgel

Hal tersebut jika tidak diimbangi dengan kualitas pendidikan yang baik maka tidak akan berdampak signifikan terhadap pertumbuhan ekonomi di Kecamatan Prambanan. Pengembangan potensi pariwisata akan terwujud, jika masyarakat Prambanan memiliki tingkat pendidikan yang tinggi. Masyarakat dapat memanfaatkan potensi wisata untuk menunjang perekonomian, sehingga dapat meningkatkan pertumbuhan ekonomi di Kecamatan Prambanan.

Perbedaan daerah dilihat dari pendapatan maupun pertumbuhan ekonomi, akan berdampak pada terpusatnya kegiatan-kegiatan ekonomi pada suatu daerah saja dan tidak terjadi persebaran yang merata (Kartini, 2008). Setiap wilayah umumnya mempunyai masalah di dalam proses pembangunannya, masalah yang paling sering muncul di wilayah tersebut adalah masalah ketimpangan pembangunan ekonomi dan kesenjangan dalam distribusi pendapatan. Ketimpangan pembangunan antar daerah dengan pusat dan antar daerah satu dengan daerah lain merupakan suatu hal yang wajar, karena adanya perbedaan dalam sumber daya dan awal pelaksanaan pembangunan antar daerah. (Williamson, dalam Hartono, 2008).

Tingkat pendidikan akan selalu beriringan dengan kondisi perekonomian masyarakat. Seseorang yang tingkat pendidikannya yang lebih tinggi, dan lamanya waktu dalam menempuh pendidikan akan berpengaruh terhadap jenis pekerjaan dan upah yang diterimanya. Menurut Simanjuntak (dalam Budiarti 2014) apabila upah pekerja mencerminkan produktivitas, maka semakin banyak penduduk yang memiliki pendidikan

\section{METODE PENELITIAN}

Jenis penelitian yang digunakan dalam penelitian ini adalah metode deskriptif kuantitatif. Penelitian deskriptif kuantitatif merupakan penelitian yang bertujuan menjelaskan fenomena yang ada dengan menggunakan angka-angka untuk mendeskripsikan karakteristik suatu individu atau kelompok. Penelitian ini menilai sifat dari kondisi-kondisi yang tampak (Syamsudin dan Damiyanti, 2011). Berdasarkan teori tersebut, penelitian deskriptif kuantitatif merupakan data yang diperoleh dari sampel populasi penelitian yang dianalisis sesuai dengan metode statistik yang digunakan. Penelitian deskriptif kuantitatif dalam penelitian ini dimaksudkan untuk mendapatkan suatu ketimpangan ekonomi terhadap tingkat pendidikan yang ada di Kecamatan Prambanan.

\section{Waktu dan Lokasi Penelitian}

Penelitian dilakukan di Kecamatan Prambanan, Jawa Tengah, yang melibatkan 16 desa yaitu desa Desa Kemudo, Desa Kebondalem Lor, Desa Kebondalem Kidul, Desa Brajan, Desa Sanggrahan, Desa Joho, Desa Cucukan, Desa Tlogo, Desa Bugisan, Desa Kotesan, Desa Randusari, Desa Sengon, Desa Kokosan, Desa Taji, Desa Geneng, dan Desa Pereng (Gambar 1). Penelitian dilakukan selama 3 bulan, dimulai sejak Bulan Maret sampai Bulan Mei 2018 meliputi tahapan persiapan, pengujian instrumen penelitian, survei lokasi penelitian, pengambilan data dan pengumpulan data, serta pembuatan peta dan pembuatan laporan.

\section{Bahan dan Data}

Jenis-jenis data yang digunakan dalam penelitian ini adalah data primer dan data sekunder. Data primer merupakan data 
Jurnal Geografi, Edukasi dan Lingkungan (JGEL) Vol. 3, No. 1, Januari 2019:26-33

P-ISSN: 2579-8499; E-ISSN: 2579-8510

DOI: https://doi.org/10.29405/jgel.v3i1.2990

Website: http://journal.uhamka.ac.id/index.php/jgel

yang diambil secara langsung pada sumbernya seperti observasi, dan wawancara. Data sekunder adalah datadata pendukung yang digunakan dalam penelitian seperti buku, jurnal, artikel, Citra Google Earth dan Peta Administrasi Kecamatan Prambanan Kabupaten Klaten di peroleh dari peta RBI skala 1:25.000. Peneliti membutuhkan pengumpulan data guna memperkuat hasil dari penelitian dengan cara berkunjung ke perpustakaan, membaca buku referensi yang berkaitan dengan judul penelitian.

\section{Analisis Data}

Analisis data dalam penelitian ini adalah analisis deskriptif dan analisis kuantitatif. Analisis deskriptif adalah analisis data dengan cara mendeskripsikan atau menggambarkan data yang telah terkumpul sebagaimana adanya tanpa bermaksud membuat kesimpulan yang berlaku untuk umum atau generalisasi. Analisis data kuantitatif adalah analisis dengan menggunakan angka-angka untuk mendeskripsikan karakteristik suatu individu atau kelompok. Metode analisis tersebut dapat digunakan untuk Mendeskripsikan kondisi ketimpangan ekonomi dan tingkat pendidikan berdasarkan unit analisis Desa.

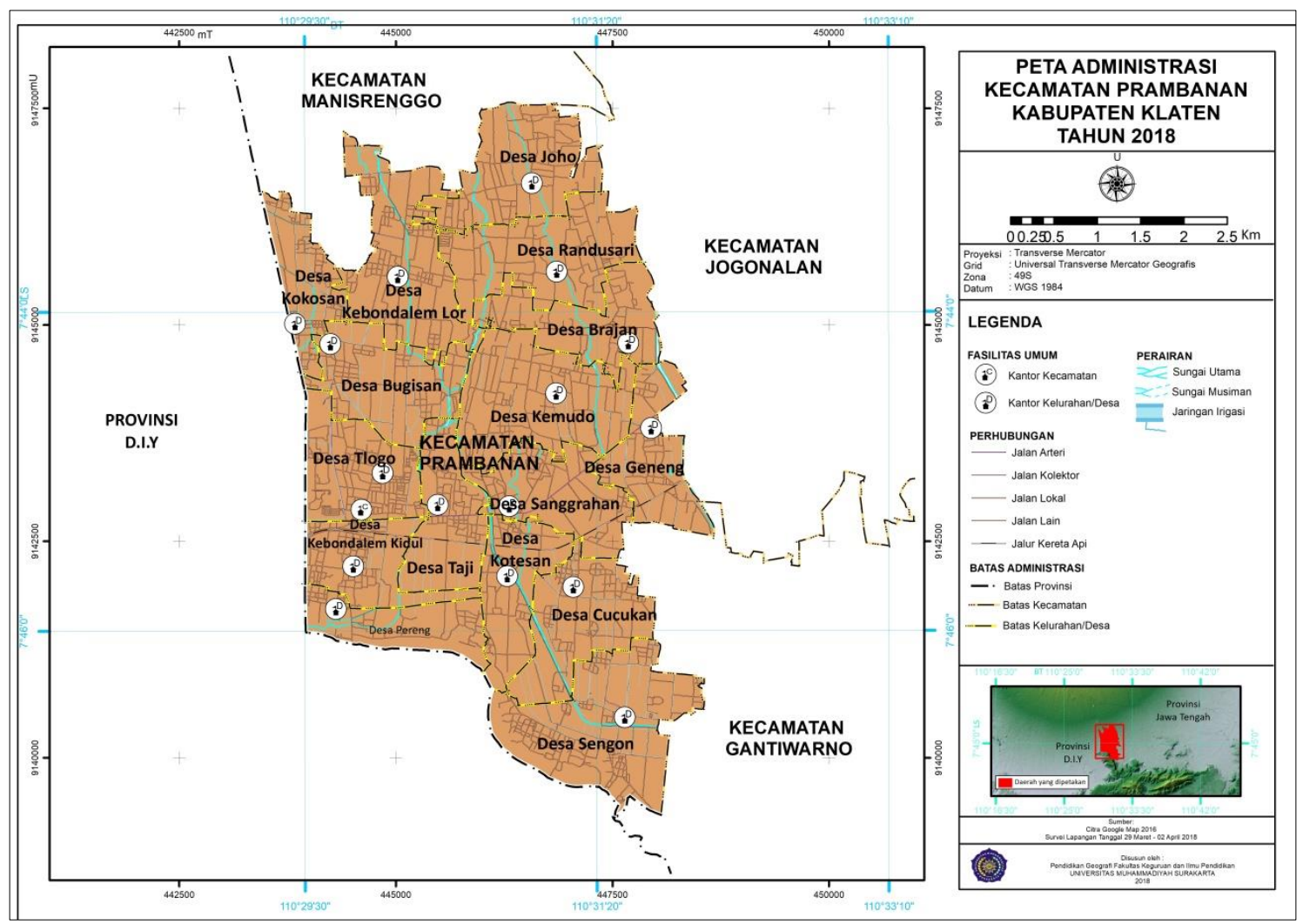

Gambar 1. Peta Administrasi Kecamatan Prambanan Tahun 2018 
Jurnal Geografi, Edukasi dan Lingkungan (JGEL) Vol. 3, No. 1, Januari 2019:26-33

P-ISSN: 2579-8499; E-ISSN: 2579-8510

DOI: https://doi.org/10.29405/jgel.v3i1.2990

Website: http://journal.uhamka.ac.id/index.php/jgel

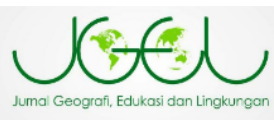

\section{HASIL DAN PEMBAHASAN Kondisi Perekonomian Di Kecamatan Prambanan}

Kondisi perekonomian di

Kecamatan Prambanan di 16 Desa merupakan beragam. Hal tersebut mengakibatkan adanya ketimpangan perekonomian di Kecamatan Prambanan, data kondisi perekonomian di 16 Desa di Kecamatan Prambanan direpresentasikan pada Grafik pendapatan warga di Kecamatan Prambanan (Gambar 2).

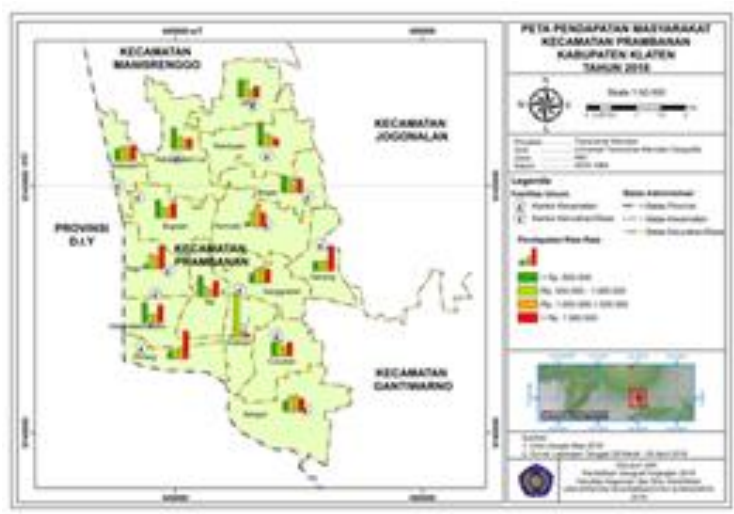

Gambar 2. Peta Pendapatan masyarakat Kecamatan Prambanan Tahun 2018.

Berdasarkan tingkat pendapatan, pendapatan masyararakat antara $\mathrm{Rp}$. 500.000 hingga Rp. 1.500.000 (Gambar 3). Pendapatan tertinggi terdapat terdapat pada Desa Kotesan, dengan persentase 78.09\% dari jumlah penduduk di desa tersebut. Desa Kotesan ini merupakan wilayah yang sangat strategis karena berdekatan dengan wilayah industri. Tidak sedikit yang bekerja sebagai petani karena kondisi wilayah yang juga padat persawahan.

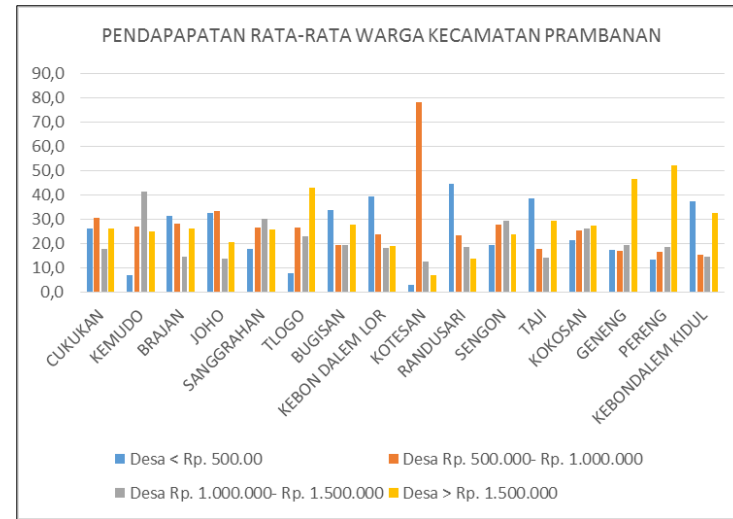

Gambar 3. Grafik pendapatan warga di Kecamatan Prambanan

\section{Kondisi Tingkat Pendidikan Masyarakat di Kecamatan Prambanan}

Pendidikan merupakan tombak dari berbagai aspek dan segi kehidupan masa depan. Pendidikan menentukan laju perekonomian, kesehatan, sikap dan perilaku, ide dan gagasan serta ideologi, pergerakan informasi dan sebagainya. Hal-hal diatas sangat sulit didapatkan jika tidak memiliki pendidikan yang baik. Kondisi tingkat pendidikan masyarakat Kecamatan Prambanan disajikan pada Gambar 4.

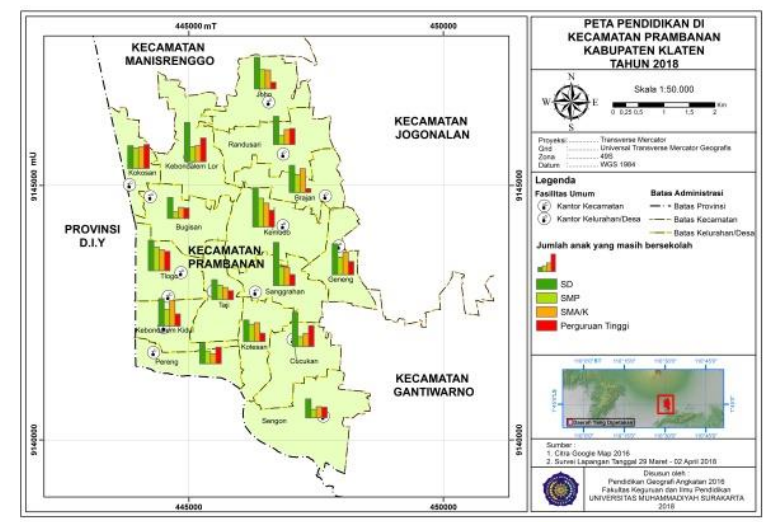

Gambar 4. Gambar peta kondisi pendidikan di Kecamatan Prambanan.

Masyarakat Prambanan sadar akan pentingnya pendidikan. Hal ini berdasarkan banyaknya masyarakat di Kecamatan Prambanan yang memasukkan anaknya ke sekolah-sekolah sesuai 
Jurnal Geografi, Edukasi dan Lingkungan (JGEL) Vol. 3, No. 1, Januari 2019:26-33

P-ISSN: 2579-8499; E-ISSN: 2579-8510

DOI: https://doi.org/10.29405/jgel.v3i1.2990

Website: http://journal.uhamka.ac.id/index.php/jgel

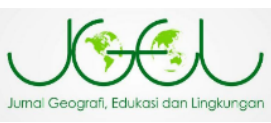

dengan kemampuan dari perekonomian masyarakat tersebut. Hasil temuan menunjukkan masyarakat Kecamatan Prambanan mampu menyekolahkan anaknya hingga SMP, SMA, atau sampai ke Perguruan Tinggi. Namun jika dibandingkan dengan wilayah lain di Indonesia, kualitas manusia di Kecamatan Prambanan tergolong baik. Kemudahan mengakses informasi dan komunikasi menjadikan masyarakat mampu memperoleh pengetahuan, baik untuk masyarakat bersekolah maupun yang tidak bersekolah. Hasil menunjukkan masyarakat yang memperoleh pendidikan, berbeda dengan yang tidak bersekolah.

Kesadaran akan pendidikan di lingkungan masyarakat Kecamatan Prambanan cukup tinggi, terutama orang tua yang tergolong masih muda-muda. Masyarakat yang menempuh pendidikan di Kecamatan Prambanan merupakan suatu gambaran untuk menentukan kualitas dari masyarakat itu sendiri. Adanya dorongan dengan berbagai macam perekonomian diketahui bahwa pendapatan bukanlah alasan utama dalam menempuh pendidikan. Hanya kualitas pendidikannya saja yang berbeda, tetapi rata-rata semua anak bersekolah (Gambar $5)$.

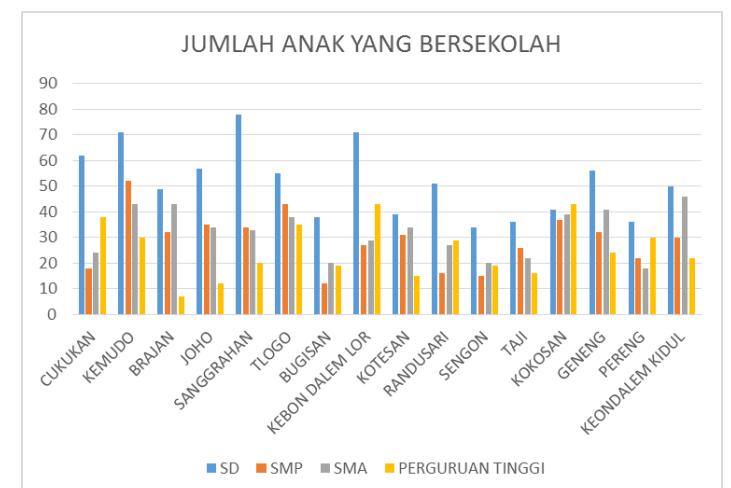

Gambar 5. Grafik jumlah anak yang bersekolah di Kecamatan Prambanan

Diketahui bahwa peserta didik paling banyak terdapat di strata pendidikan tingkat SD. Hal ini juga berbanding lurus dengan jumlah anakanak usia 7-14 tahun terbanyak dibanding penduduk usia lainnya. Selain itu, kesadaran pendidikan yang tinggi sehingga peserta didik SD paling banyak. Terdapat pola pikir yang terbangun juga karena para orang tua tidak ingin anakanaknya seperti mereka yang putus sekolah. Para orang tua ingin anakanaknya dapat bersekolah dengan baik hinga perguruan tinggi dan memperoleh pekerjaan yang layak dan baik.

\section{Analisis Ketimpangan Perekonomian Terhadap Tingkat Pendidikan Masyarakat Di Kecamatan Prambanan Kondisi perekonomian di} Kecamatan Prambanan sangat beragam, hal tersebut mengakibatkan adanya ketimpangan perekonomian di Kecamatan Prambanan. Berdasarkan pendapatan rata rata di kecamatan prambanan dapat di ketahui bahwa Desa Randusari merupakan desa dengan penduduk dengan tingkat pendapatan kurang dari Rp 500.000 paling banyak dari 16 desa di kecamatan prambanan dan memiliki tingkat pendidikan mencapai $83,67 \%$. Hal ini tentu bertentangan dengan pendapatannya yang mayoritas dibawah Rp 500.000, tetapi memiliki jumlah anak yang bersekolah cukup tinggi.

Kecamatan Prambanan merupakan daerah pariwisata yang sangat menunjang perekonomian daerah dan ekonomi masyarakat. Hal ini dapat dilihat dari banyaknya turis dan kedekatan wilayah dengan pusat kota Yogyakarta yang notabenenya merupakan kota budaya. Adanya keragaman gerakan perekonomian juga menentukan kualitas dari masyarakat terutama dibidang pendidikan.

Daya

masyarakat dalam memperoleh pendapatan tidak terlalu menentukan tingkat pendidikan dari 
Jurnal Geografi, Edukasi dan Lingkungan (JGEL) Vol. 3, No. 1, Januari 2019:26-33

P-ISSN: 2579-8499; E-ISSN: 2579-8510

DOI: https://doi.org/10.29405/jgel.v3i1.2990

Website: http://journal.uhamka.ac.id/index.php/jgel

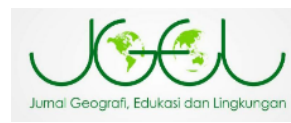

masyarakat terutama penduduk yang telah memiliki anak. Pendapatan yang layak berpotensi terhadap terjangkaunya pendidikan yang layak, sehingga akan tercipta masyarakat yang cerdas dan menunjang pembangunan di wilayah itu sendiri. Identifikasi beberapa faktor untuk mendorong peningkatan daya pendapatan masyarakat merupakan penting, sehingga dapat teridentifikasi mampu atau tidaknya masyarakat dalam menyikapi Prambanan yang mempunyai merk dimata nasional maupun internasional.

Penduduk Prambanan mempunyai mata pencaharian yang beragam. Adanya objek wisata disekitarnya bukan berarti mereka harus menggantungkan hidup dari icon tersebut. Banyak dari mereka yang tetap menjalankan kegiatan seperti bertani. Wilayah kecamatan ini memiliki kawasan agraris yang sangat luas sekali. Tidak menjadi sesuatu yang aneh jika wisatawan sering bertemu dengan petani.

Selain itu, daerah ini memiliki banyak kegiatan industri dari muali tekstil hingga produksi pangan. Maka masyarakat disini selain bertani, banyak yang bekerja sebagai buruh. Tidak jarang dalam satu rumah sering dijumpai anggota keluarga yang pekerjaannya bertani dan buruh dalam satu rumah. Tentu ini sangat kontras jika dikaitkan dengan Prambanan yang besar sebagai daerah wisata. Menurut penuturan beberapa responden juga mengatakan bahwa kehadiran daearah wisata tidak berpengaruh apa-apa dalam segi perekonomian mereka.

Kecamatan Prambanan tidak hanya merupakan daerah yang namanya besar akibat pariwisatanya saja. Cukup banyak sektor lain yang membentuk karakter dari Prambanan tersebut. Sebagai contoh wilayah ini memiliki banyak sekali persawahan. Desa-desa di Prambanan bagian utara khususnya bagian selatan penuh dengan persawahan. Masyarakat disana juga banyak yang notabennya sebagai petani. Bagian wilayah yang mendekatai ke jalan utama mulai penuh dengan berbagai toko dan pabrik-pabrik. Selain petani juga dalam suatu keluarga rata-rata masyarakat berprofesi sebagai buruh di pabrik-pabrik tersebut.

Wilayah Prambanan tidak lepas dari fasilitas pendidikan yang baik. Hal ini dilihat dari banyaknya sekolah yang berada disana. Walaupun tidak semua masyarakat Prambanan menaruh anaknya di sekolahan yang berada di Prambanan, namun tidak sedikit juga yang memilih untuk tetap berada di lingkup wilayah tersebut dikarenakan akses dan keterjangkauan berbagai aspek.

Pendidikan di daerah Prambanan dinilai cukup memadai. Hampir semua kalangan dari yang memiliki ekonomi kecil, menengah dan atas semuanya memperoleh pendidikan. Hanya saja jenis dan kualitas dari pendidikan yang diambil berbeda beda. Untuk yang memiliki perekonomian yang baik memilih untuk bersekolah di sekolah yang mengeluarkan cukup banyak biaya. Sebaliknya, masyarakat yang memiliki ekonomi rendah banyak yang memilih sekolah yang telah dibiayai pemerintah.

Pendapatan masyarakat tiap desa yang berada di Kecamatan Prambanan yang memiiki keragaman ekonomi. Hal ini membuat setiap orang yang mempunyai pendapatan yang beragam. Selain itu, akibat dari beragamnya tingkat ekonomi memengaruhi tingkat kependidikan masyarakat. Faktor-faktor yang membuat ekonomi dan pendidikan saling memengaruhi adalah seperti jumlah penghasilan dan pengeluaran tiap bulan tiap-tiap individu.

Pendapatan tertinggi rata-rata masyarakat Kecamatan Prambanan Rp. 1.500.000, diduduki oleh Desa Pereng dengan persentase $52,04 \%$. Hal ini didasarkan atas masyarakat desa tersebut 
Jurnal Geografi, Edukasi dan Lingkungan (JGEL) Vol. 3, No. 1, Januari 2019:26-33

P-ISSN: 2579-8499; E-ISSN: 2579-8510

DOI: https://doi.org/10.29405/jgel.v3i1.2990

Website: http://journal.uhamka.ac.id/index.php/jgel

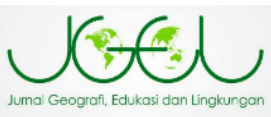

yang mata pencahariannya heterogen. Tidak sedikit yang bekerja sebagai PNS, Wiraswasta, Kepala Sekolah, Guru, dan ada beberapa pensiunan. Hal ini sangat menunjang perekonomian masyarakat setempat. Kondisi tersebut mengakibatkan hampir semua anggota keluarga terkhusus anak-anak mereka semuanya bersekolah.

Orang tua di Kecamatan Prambanan memiliki pemahaman yang baik yaitu bahwa pendidikan merupakan hal yang penting. Beberapa dari mereka memberi alasan seperti; pendidikan itu penting, agar dapat memperoleh pekerjaan yang layak, untuk masuk perguruan tinggi yang baik, ingin melebihi orang tua, dan lain sebagainya. Namun ada pula yang memberi alasan seperti karena adanya tekanan, akan tetapi jawaban tersebut dengan presentase kecil.

Kemampuan masyarakat dalam memperoleh pendapatan membuat pendidikan di setiap desa mengalami kesenjangan. Masyarakat yang berpendapatan rendah rata-rata memasukkan anaknya di sekolah gratis yang dibiayai negara. Ha ini menunjukkan bahwa perekonomian masyarakat yang paling besar terdapat pada desa Desa Pereng. Taraf pendidikan di desa tersebut juga memiliki kategori baik. Hal ini ditinjau dari banyaknya masyarakat yang menyekolahkan anak-anaknya ke sekolah dengan kategori baik .

\section{KESIMPULAN}

Tingkat pendapatan dan ekonomi masyarakat tidak memengaruhi kemauan masyarakat dalam memperoleh pendidikan dari segala kalangan umur. Kemampuan mata pencaharian dan pendapatan yang heterogen tentunya merupakan parameter yang paling mencolok dalam melihat kemampuan memperoleh pendidikan masyarakat tersebut. Populasi dari masyarakat usia 714 tahun yang lebih banyak menyebabkan penempuh pendidikan tingkat SD lebih banyak dari masyarakat usia lainnya. Ketersediaan fasilitas pendidikan di Kecamatan Prambanan yang cukup menampung hampir semua masyarakat penempuh pendidikan di kecamatan tersebut.

\section{DAFTAR PUSTAKA}

Budiarti, Devi. 2014. "Pengaruh Tingkat Pendidikan Terhadap Pertumbuhan Ekonomi Di Kabupaten Mojokerto Tahun 2000-2011". Jurnal Pendidikan Ekonomi. Vol 2, Nomor 1. Universitas Negeri Surabaya. Surabaya.

Gama, Ayu Savitri. (2009). "Disparitas Dan Konvergensi Produk Domestik Regional Bruto (PDRB) Per Kapita Antar Kabupaten/Kota Di Provinsi Bali”. Jurnal Ekonomi Dan Sosial. Volume 2 Nomor 1. Universitas Udayana, Bali.

Hartanto, Budiarto. (2008). "Analisis Ketimpangan Pembangunan Ekonomi Di Provinsi Jawa Tengah". Tesis. Universitas Diponegoro.

Semarang.

Kartini, T. (2008). Hubungan antara Kinerja Lingkungan dan Kinerja Ekonomi. Jakarta: Universitas Indonesia.

Raharjo, Sabar Budi. (2012). "Evaluasi Trend Kualitas Pendidikan Di Indonesia". Jurnal Penelitian Dan Evaluai Pendidikan. Nomor 2. Balitbang Kemendiknas.

Riswandi, 2009. Hubungan Kausalitas Jangka Panjang Investasi Penidikan dengan Pertumbuhan Ekonomi: Studi Kasus Provinsi Aceh melalui Analisid Vector Autoregression (VAR).

Syamsuddin, 011. Metode Penelitian Pendidikan Bahasa. Bandung: PT. Remaja Rosdakarya. 